\title{
Description of the final instar larva of Argia serva Hagen in Selys, 1865 (Odonata Coenagrionidae)
}

\author{
ALEJANDRO DEL PALACIO, FEDERICO LOZANO and JAVIER MUZÓN \\ Laboratorio de Biodiversidad y Genética Ambiental (BioGeA), Universidad Nacional de \\ Avellaneda, Mario Bravo 1460 esq. Isleta, C.P. 1870, Piñeyro, Buenos Aires, Argentina
}

Manuscript received on January 29, 2018; accepted for publication on April 9, 2018

\begin{abstract}
The American genus Argia, with more than 100 species described, is the most speciose genus of Odonata in the world. In this contribution, the final stadium larva of Argia serva, the southernmost distributed species of Argia, is described and diagnosed based on reared material from Martín García island, Buenos Aires, Argentina. The larva of this species can be easily separated from the other Argentinean Argia by the following combination of characters: sternum of S8 covered with spines (bare in A. translata); antennal segment 3 longer than 1+2 (equal to or shorter than 1+2 in A. joergenseni and A. jujuya); palpal setae absent (present in A. croceipennis). A key to the known larvae of Argia of the Southern Cone is provided.
\end{abstract}

Key words: Argia, Coenagrionidae, Odonata, Zygoptera, Southern Cone.

\section{INTRODUCTION}

The American genus Argia, with 123 species described (Garrison and von Ellenrieder 2017) and many more species under description, is the most speciose genus of Odonata in the world. The genus includes small (21 $\mathrm{mm}$ in A. bicellulata) to large (57 $\mathrm{mm}$ in $A$. funcki) coenagrionids which are generally black and blue or violet (Garrison and von Ellenrieder 2015); tibial spurs are as long as or longer than twice the intervening spaces; wings are hyaline or tinged with amber or entirely brown; genital ligula variable; males with tori (pillowshaped pads on postero-dorsal margin of S10); male cerci generally entire with basal processes; females without vulvar spine. Larvae are common

Correspondence to: Alejandro del Palacio

E-mail: adelpalacio@undav.edu.ar inhabitants of lotic environments, most species of Argia prefer low to mid order streams (Westfall and May 1996; Caesar and Wenzel 2009); labium lacks well developed dorso-apical premental setae; labial palp usually with 1-4 setae, distally ending in two hooks; caudal lamellae generally ending in a filamentous tip (Novelo-Gutiérrez 1992).

The Southern Cone is a geographic region composed of the southernmost areas of South America, south of and around the Tropic of Capricorn; it includes Argentina, Chile, Uruguay, Paraguay, and southern Brazil (Santa Catarina, Rio Grande do Sul, Paraná and São Paulo). In this area 16 species have been recorded: A. albistigma Hagen in Selys, A. croceipennis Selys, A. cyathigera Navás, $A$. hasemani Calvert, $A$. indocilis Navás, $A$. iralai Calvert, $A$. joergenseni Ris, A. jujuya Ris, $A$. 
lilacina Selys, A. modesta Selys, A. mollis Hagen in Selys, A. reclusa Selys, A. serva Hagen in Selys, A. sordida Hagen in Selys, A. translata Hagen in Selys, and A. yungensis Garrison \& von Ellenrieder (Lencioni 2006; von Ellenrieder and Muzón 2008). From these the larvae of only five have been described: A. croceipennis, A. joergenseni, A. jujuya, A. sordida, and A. translata (Costa et al. 2008; Geijskes 1946; Molineri and Rodriguez 2013; Santos 1968; von Ellenrieder 2007). In this contribution the final stadium larvae of Argia serva, the southernmost distributed species of Argia, is described an illustrated based on reared material from Martín García island, Buenos Aires, Argentina; Scanning Electron Microscope (SEM) pictures of diagnostic characters are given.

\section{MATERIALS AND METHODS}

Martín García island is a Multiple-Use Reserve located in the upper Río de la Plata estuary (Fig. 1). This island is an outcropping of crystalline Brazilian basement from the Precambrian Era covered by Quaternary Era sediments (Ravizza 1984); its coasts are asymmetric, the western coast receives silty material from the Paraná River, whereas the eastern and southern coasts are rocky but could be occasionally covered by silty sandy sediments due to south-eastern winds (Cesar 2014).

The larvae of Argia serva were found under partially submerged rocks on the southern coast of the island; they were collected with entomological tweezers, taken to the laboratory and reared in individual plastic containers. Larvae were fed with mosquitos' larvae and pupae until emergence. Teneral adults were kept alive until coloration was fixed; then they were injected with $96 \%$ ethanol and dried with silica gel. Specimens were studied with the aid of a Leica MS5 stereomicroscope in the Laboratorio de Biodiversidad y Genética Ambiental (BioGeA) of the Universidad Nacional de Avellaneda (UNDAV). Illustrations were

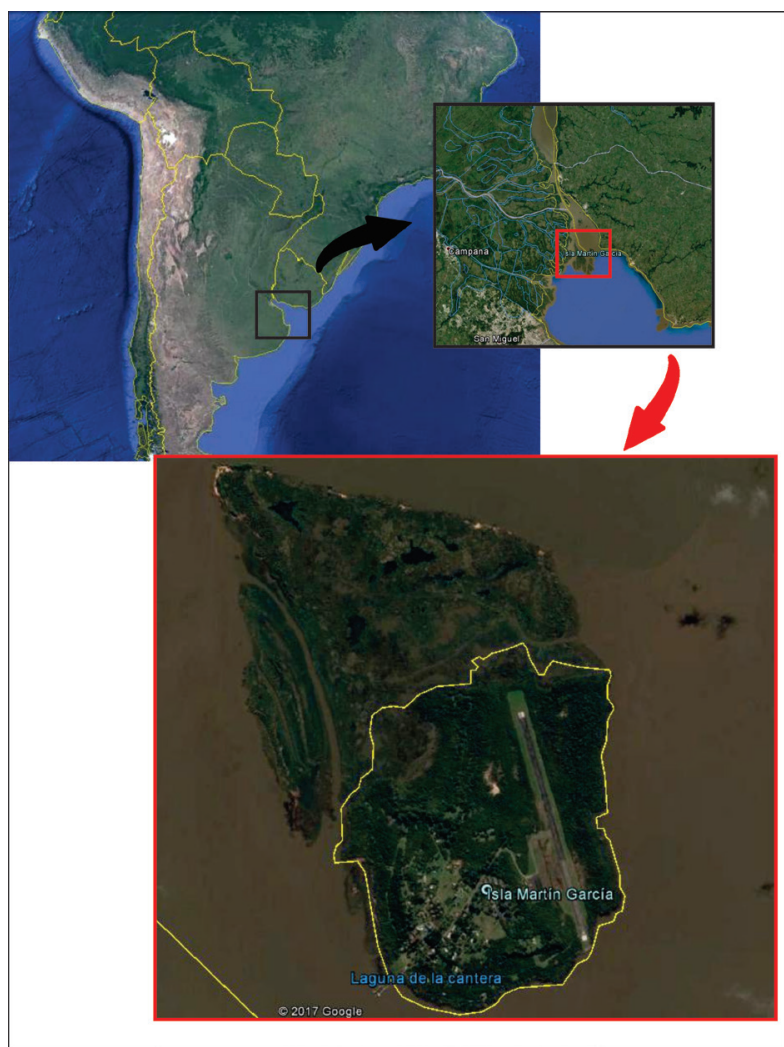

Figure 1 - Map of the known localities of Argia serva.

made with the aid of a digital camera coupled to the stereomicroscope and an open-source design program (Inkscape version 0.91. at $<$ www.inkscape. org $>$ ) and are not to scale. Specimens for SEM were cleaned in acetone, air dried and mounted on SEM stubs with carbon-conductive adhesive tabs, and then sputter coated with gold/ palladium alloy and examined with a Jeol JSM 6360 LV scanning electron microscope in the Museo de La Plata, Buenos Aires, Argentina.

\section{RESULTS}

Argia serva Hagen in Selys, 1865

(Figure 2)

Specimens examined: $4 \delta$ and 1 \% . Argentina: Buenos Aires: Isla Martín García, 34¹1'20.37'S 58 14'45.78”'W, 24.xi.2016, Lozano \& del Palacio legs., BioGeA. 


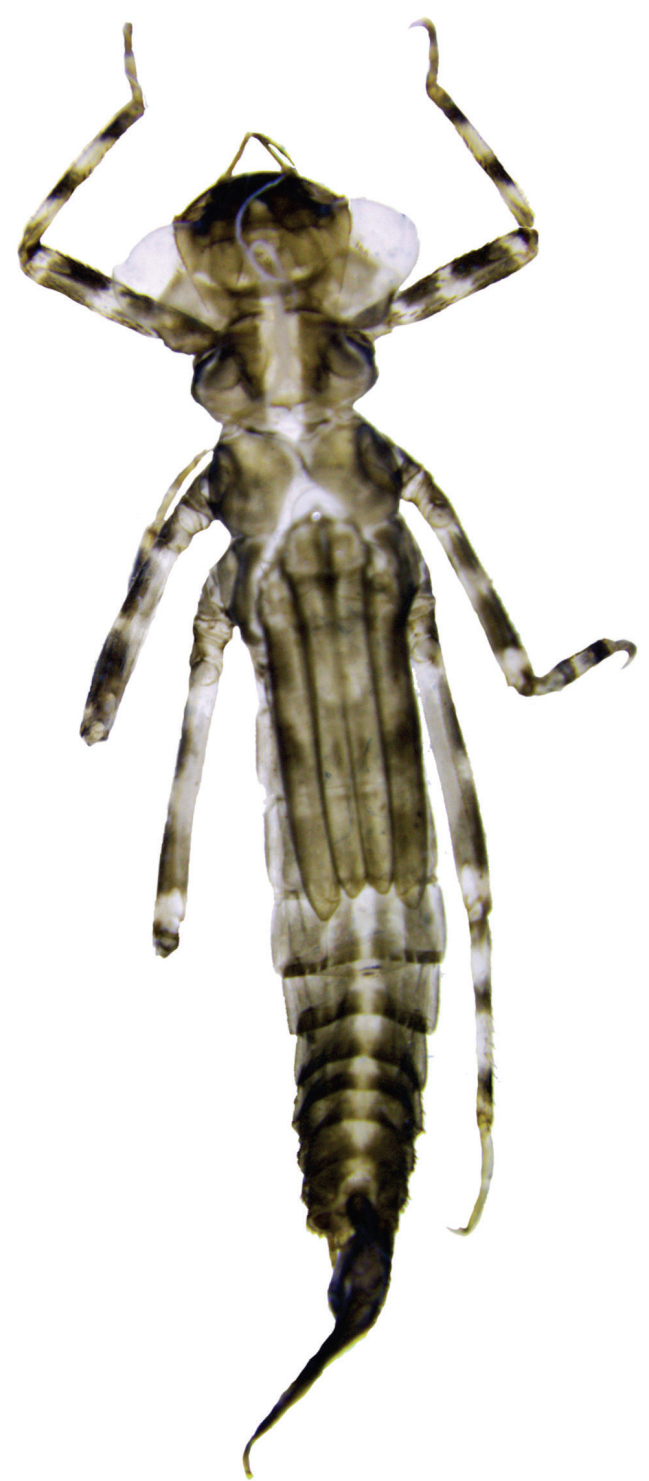

Figure 2 - Exuvia of Argia serva dorsal view.

\section{LARVAL DESCRIPTION}

Head: at least two times wider than long, with posterior margin slightly concave, cephalic lobes with several short spines. Antennae (Fig. 3a): with seven segments, third antennomere the longest, longer than $1+2(0.18,0.26,0.57,0.32,0.21$, $0.13,0.09)$. Labium: prementum - postmentum articulation reaching first coxae. Prementum (Fig. $3 b)$ : subquadrangular, longer than wide; ventral surface bare; dorsal surface with a group of 5-8 latero-basal short setae on each side of midline; lateral margin with 15-17 spiniform setae; 3-4 setae on the articulation with the palp; ligula very prominent and convex, strongly crenulated with 51-56 small setae along margin. Labial palp (Fig. $3 c)$ with two teeth shorter than movable hook, the medial one the shortest; outer margin with 11-15 spiniform setae; 1 short palpal seta basal to movable hook. Mandibles (Fig.3d) with molar teeth but without molar crest. Mandibular formula: L $1+2340$ a b, R $1+234$ y 0 b. Maxillae's stipes with small short setae; inner lobe (galea + lacinia) with four strong teeth directed medially and 11 setae near the basal part; outer lobe (palp) with pointed sclerotized apex and setae on distal half.

Thorax: wing pads parallel reaching S5 or S6; legs pale with dark bands on tibiae and femora as in Fig. 4a.

Abdomen: cylindrical, dark brown with mediolongitudinal pale stripe and two latero-longitudinal pale spots on each side on S3-7; dorsal and ventral surface of S1-6 nearly smooth, with few scattered spiniform setae, terga and sterna of S7-10 with spiniform setae increasing in number posteriorly; with a row of lateral robust spiniform setae on S9-10. Male gonapophyses (Fig. 4c) slender and pyramidal reaching almost distal margin of S10, sharply pointed and slightly diverging distally; with setae along ventral margin; female gonapophyses (Fig. 4b) surpassing distal margin of S10; outer ones with apices sharply pointed and slightly divergent, with spiniform setae along ventral surface.

Caudal lamellae foliaceous, ending in filamentous tip; very few (3-5) dorsal and ventral setae restricted to the base of the lamellae; colour pattern as in figure $4 \mathrm{~d}$.

Measurements (given in $\mathrm{mm}$; $\mathrm{N}=4$, unless stated otherwise): Head: max. length: 1.60 [1.311.84]; max. width: 2.81 [2.49-2.99]. Prementum: max. length: 2.24 [1.99-2.48]; max. width: 1.86 [1.37-2.18]. Labial palp: max. length: 1.17 [0.931.24]; max. width: 0.29 [0.24-0.37]; movable 
$\mathbf{a}$

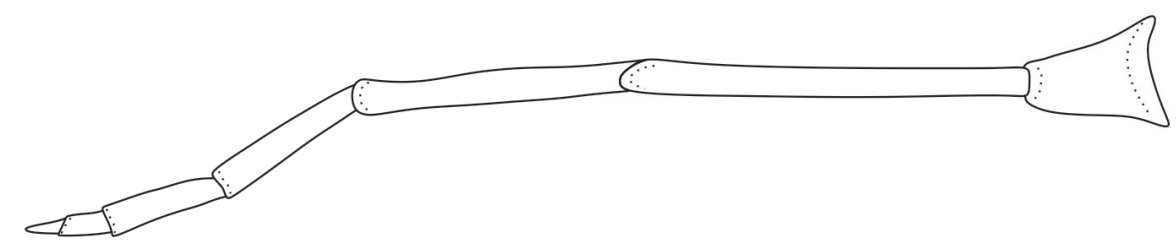

b
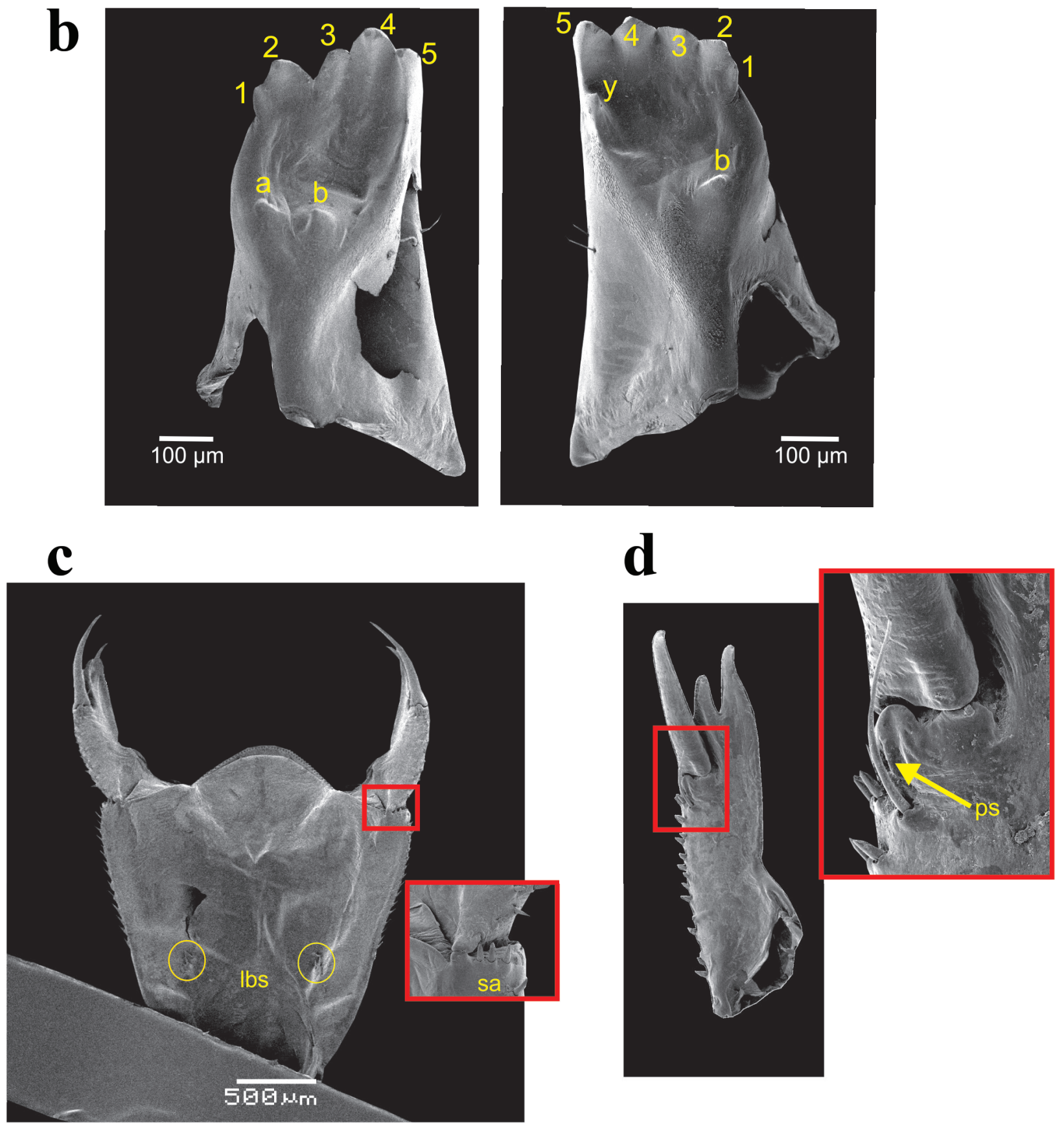

Figure 3 - (a) Right antenna dorsal view; (b) Prementum and setae on labial palp articulation; (c) Labial palp; (d) Mandibles. 

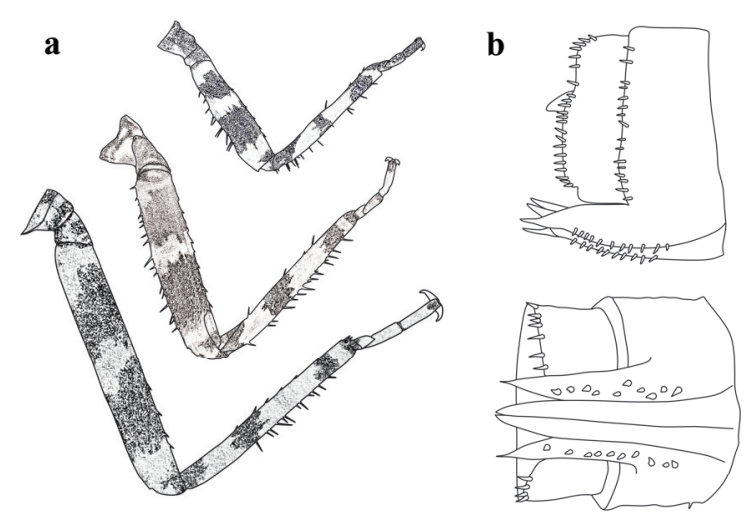

c

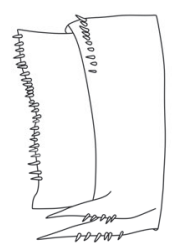

d
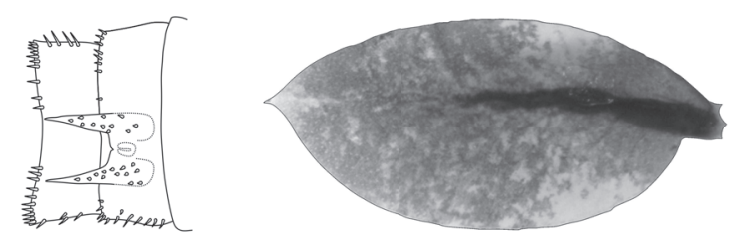

Figure 4 - (a) Legs color pattern; (b) Female gonapophyses lateral and ventral view; (c) Male gonapophyses lateral and ventral view; (d) Caudal lamella dorsal view.

hook length: 0.61 [0.58-0.64]. Legs: femur III: 3.16 [2.93-3.49]; tibia III: 2.93 [2.74-3.11]. Inner wingpad: max. length: 4.25 [3.86-4.48]. Outer wingpad: max. length: 4.02 [3.61-4.39]. Abdomen: total length: 6.32 [5.35-7.47]. Lateral caudal lamella: length $(\mathrm{N}=3): 3.74$ [3.74-3.86]. Dorsal caudal lamella: length: 2.96 [2.74-3.36].

\section{HABITAT AND DIAGNOSIS}

Larvae were found under rocks in ponds connected to the shore of the river (Fig. 5). At the time of collection, adults were seen in tandem around the larval habitat. No ovipositions were seen.

Argia serva can be easily separated from the other Argentinean Argia by the following combination of characters: sternum of S8 covered with spines (bare in A. translata); antennal segment 3 longer than $1+2$ (equal to or shorter than $1+2$ in
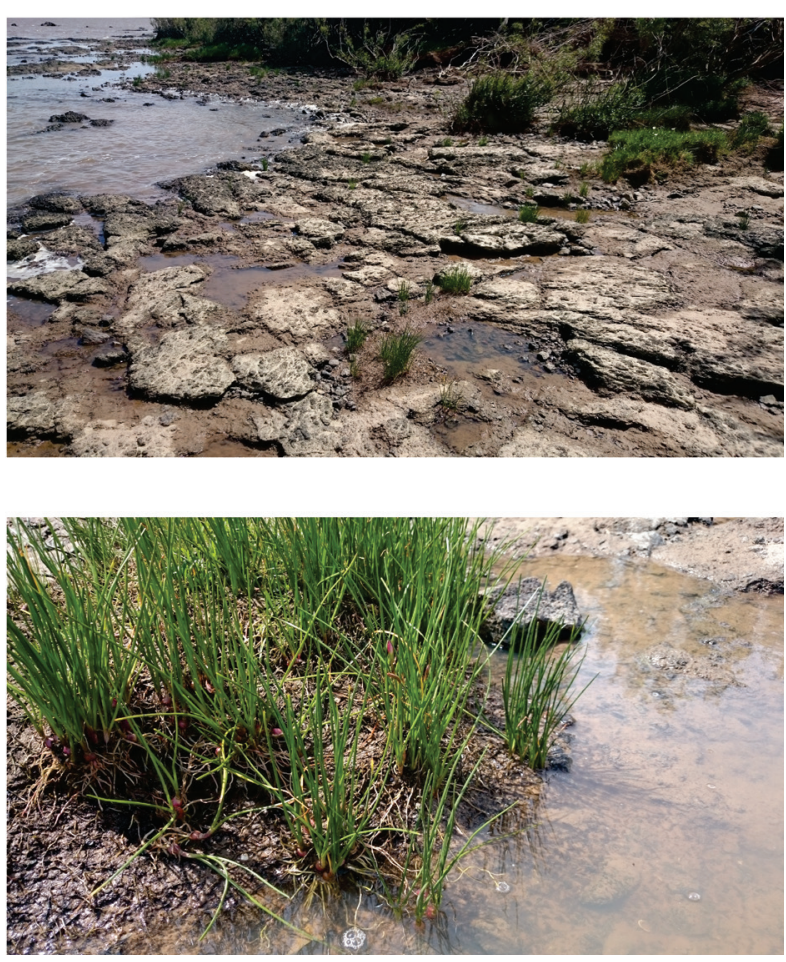

Figure 5 - Habitat where the larvae were collected.

A. joergenseni and A. jujuya); palpal setae absent (present in A. croceipennis).

\section{KEY TO THE LARVAE OF ARGIA OF THE SOUTHERN CONE}

1. Antennae with 6 segments ... A. jujuya

1 '. Antennae with 7 segments ... 2

2. Base of prementum and labial palp without spines ... A. sordida

2'. Base of prementum and labial palp with spines ... 3

3. Abdomen without setae, mandibles with molar crest and with molar tooth a ... A. translata

3'. Abdomen with setae, mandibles without molar crest and without molar tooth a ... 4

4. Femur III without dark bands, 2-3 premental spines ... A. croceipennis

4'. Femur III with dark bands, more than 3 premental spines ... 5

5. 2-3 rows of spines along gonapophyses (male and female) ...A. joergerseni 
5'. 1 row of spines along gonapophyses (male and female) ... A. serva.

\section{ACKNOWLEDGMENTS}

The authors would like to thank Rosser W. Garrison for the information on the distribution of the genus Argia.

\section{REFERENCES}

CAESAR RN AND WENZEL JW. 2009. A phylogenetic test of classical species groups in Argia (Odonata: Coenagrionidae). EntAmer 115(2): 97-108.

CÉSAR II. 2014. Annelida (Oligochaeta and Aphanoneura) from the Natural Reserve of Isla Martín García (upper Río de la Plata estuary, Argentina): biodiversity and response to environmental variables. Braz J Biol 74(1): 128-136.

COSTA JM, RAVANELLO CT AND SOUZA-FRANCO GM. 2008. The larva of Argia croceipennis Selys (Zygoptera: Coenagrionidae). Odonatologica 37(3): 265-271.

GARRISON RW AND VON ELLENRIEDER N. 2015. Damselflies of the genus Argia of the Guiana Shield (Odonata: Coenagrionidae). Zootaxa 4042(1): 1-134.

GARRISON RW AND VON ELLENRIEDER N. 2017. New species of the damselfly genus Argia from Mexico, Central
America and Ecuador with an emphasis on Costa Rica (Insecta: Odonata: Coenagrionidae). Zootaxa 4235: 1-93. GEIJSKES DC. 1946. Observations on the Odonata of Tobago, B.W. I. Trans R Entomol Soc Lond 97: 213-235.

LENCIONI FAA. 2006. Damselflies of Brazil. An illustrated identification guide. 2 - Coenagrionidae, Sao Paulo: All Print Editora, viii +419 p.

MOLINERI C AND RODRIGUEZ JS. 2013. Description of the larva of Argia jujuya Ris (Coenagrionidae) with a key to species from the Argentinean Yungas cloud forest. IJO 16(4): 301-307.

NOVELO-GUTIERREZ R. 1992. Biosystematics of the larvae of the genus Argia in Mexico (Zygoptera: Coenagrionidae). Odonatologica 21(1): 39-71.

RAVIZZA GB. 1984. Principales aspectos geológicos del cuaternario en la isla Martín García, Río de la Plata Superior. Rev Asoc Geol Argent 39(1-2): 125-130.

SANTOS ND. 1968. Fauna do Estado da Guanabara 64 - Descrição da ninfa de "Argia sordida" Selys, 1865 (Odonata: Coenagriidae). Atas Soc Biol Rio de Janeiro 11(6): 227-228.

VON ELLENRIEDER N. 2007. The larva of Argia joergenseni Ris (Zygoptera: Coenagrionidae). Odonatologica 36: 8294.

VON ELLENRIEDER N. AND MUZÓN J. 2008. An updated checklist of the Odonata from Argentina. Odonatologica 37(1): 55-68.

WESTFALL MJ AND MAY ML. 1996. Damselflies of North America, Gainsville: Scientific Publishers, 649 p. 